\title{
Latin and the Vernaculars: The Case of Erasmus
}

\author{
Ari H. Wesseling †
}

Just imagine the Colloquies written in the racy Dutch of the sixteenth century! What could he not have produced if, instead of gleaning and commenting upon ancient adages, he had made a collection of Dutch proverbs? ${ }^{1}$

The interaction and competition between Latin and the vernacular languages is a fascinating feature of the Renaissance and the Reformation. ${ }^{2}$ Many authors were bilingual; the names of Petrarch, More, and Milton spring to mind, not to mention Luther, Ulrich von Hutten, and Zwingli. Erasmus, by contrast, wrote Latin exclusively. On the basis of his lifelong devotion to the cause of classical Latinity, one might infer, with Huizinga, that he had no use for vernacular proverbs. The opposite, however, is true. In the Adagia he quotes-in Latin translation-over 250 sayings of Dutch provenance. A rare and, in fact, unique testimony to his interest in the vernacular is found in the Collectanea (1500). In it he quotes and explains a Dutch proverb as an independent item (no. 723), on a par with ancient adages, and notes that he includes it out of respect for the popular speech of his day ('ne nihil a vulgo mutuati videamur neve nostram aetatem usquequaque contempsisse'). That he includes a Dutch proverb in his (earliest) collection of ancient adages is certainly surprising. Although he never used it in other works, it must have been one of his favourite proverbs. It has all the characteristics of an adage, he says, except that it is neither ancient nor found in a classical author. He quotes the proverb in the following way: 'Prospectandum vetulo cane latrante.' The Dutch original is 'Als die oude hont bast so salmen uutsien' ('Beware when the old dog is barking', that is, an old watch dog never barks without good reason). The sense is: when a greybeard gives the alarm, there is real danger lurking. ${ }^{3}$

1 Huizinga, Erasmus of Rotterdam, p. 54.

2 This article is partly based on my 'Dutch Proverbs and Ancient Sources'.

3 ASD II, 9, pp. 243-44, ll. 270-75. See Suringar, no. 70. Petrus Montanus plagiarized this item from Erasmus's Collectanea and included it in his own Adagia (1504). He appended a piece of propaganda 'pro Germania' against the cultural superiority of the Italians. See the commentary on Erasmus, Adagia 3535, ASD II, 8, p. 43. 
He follows it with two other proverbs on barking dogs. The first, no. 724, 'Canes qui plurimum latrant, perraro mordent' ('Barking dogs don't bite'), may well be of vernacular provenance as well. Anyway, it is not found in this form in ancient authors. It is in Walther's dictionary of medieval Latin proverbs, but the source cited there is late, dating from the 17 th century. ${ }^{4}$ Erasmus notes: 'This proverb, too, ${ }^{5}$ is used nowadays to refer to slanderous and menacing people' ('Dicitur hac aetate et hoc in homines maledicos et minaces'). Equivalents from Dutch and German are quoted by Suringar; the Dutch equivalent is 'Blaffende honden bijten niet', the German one 'Hunde die bellen, beissen nicht'.

His comment on the second, no. 725 , 'Canes omnibus ignotis allatrant' ('Dogs bark at everyone they don't know'), is very brief. He merely notes that it applies to people who rebuke what they fail to understand, 'in eos qui quicquid non intelligunt, id damnant ac repraehendunt. ${ }^{7} \mathrm{He}$ undoubtedly took this from Giovanni Pico's famous Oratio de dignitate hominis (6o): defending the noble science of natural magic, which explores the mysterious harmony of the universe, Pico concludes: 'Et haec satis de magia, de qua haec diximus, quod scio esse plures qui, sicut canes ignotos semper adlatrant, ita et ipsi saepe

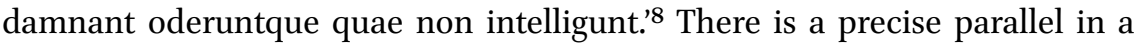

4 No. 2287a 'Canes plurimum latrantes raro mordent,' quoted from ms Cassel, Philolog. $8^{\wedge}$ $\left\{{ }^{* * *}\right\} 11$ (s. xvii), fol. 27 .

5 ASD II, 9, p. 244, ll. 276-78. 'Et' in Erasmus's comment refers back to no. 722, a Greek proverb on the subject of vain threats. It may seem strange that 'et' should not refer to the immediately preceding item, but such editorial irregularities are not uncommon for Erasmus, at least in the Adagia (for a striking example see no. 3774, ASD II, 8, p. 164, ll. 828-32). I surmise that he incorporated no. 723 into the materials for the 1500 edition only at a later stage.

6 Sartorius, Adagiorum chiliades tres, no. 2778, quoted by Suringar, no. 34. See also Singer, s.v. Hund, nrs. 346-58; a French version (no. 349) is 'Chacun chien qui aboye ne mort pas' (Not every barking dog bites). The Latin proverb in Erasmus' Collectanea also appears in Fausto Andrelini's Epistolae proverbiales (at the end of no. 2), printed in 1508; but its composition dates back to 1490, which raises the question as to who borrowed from whom; see Contemporaries of Erasmus, s.v. Andrelini, 1, p. 55. See also the head-note on Adagia 2700 (entitled 'Canes timidi vehementius latrant'), $A S D$ II, 6, p. 479.

7 ASD II, 9, p. 244, ll. 279-80, and the commentary of Van Poll, p. 245.

8 Erasmus flouts natural magic along with alchemy in his defense of the Colloquies, ASD I, 3 , p. 746, ll. 199-202. He quotes another expression explicitly from Pico ('Picus Mirandulanus') in Collectanea 466, namely, 'Non omnia pari filo conuenit,' while expressing doubt as to its antiquity ('e medio fortasse sumptum'). Accordingly, he excluded it from the Adagia. (It may have escaped his attention that Pico apparently borrowed from Lucretius, De rerum natura 2.340-41: 'Debent ... non ... omnia prorsum esse pari filo,' i.e. 'It must needs be that not all [atoms] are of equal size.') In the preface to the Collectanea Erasmus counts Pico, Ermolao Barbaro, and Angelo Poliziano among the greatest authors ('maximi authores') and praises 


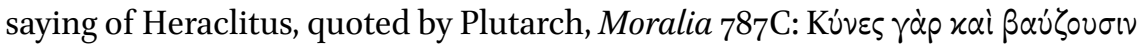

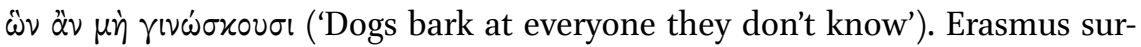
prisingly never refers to the Greek saying.

These three proverbs do not reappear in the Adagia, with the exception of no. 723 , relegated to the very end of Adagia no. 208 to illustrate the ancient proverb 'Eum ausculta, cui quatuor sunt aures' ('Listen to the person who has four ears')..$^{9}$ Erasmus wanted to limit the enlarged collection exclusively to ancient adages; ${ }^{10}$ this also explains why he suppressed his praise for the NeoLatin authors Pico, Barbaro, and Poliziano in the new introduction. One can only speculate as to why he decided to exclude no. 725, a truly ancient adage, from the enlarged collection. It seems that the passage in Plutarch escaped his attention (he translated several moral essays of Plutarch, but not the one in question).

As noted above, the presence of vernacular proverbs in the Adagia is quite strong. An interesting example is found in Erasmus's explanation of 'a Sardonic laugh.' He illustrates the ancient etymology of this expression ( $\dot{\alpha} \pi \dot{o}$ $\tau 0 \hat{~ \sigma \varepsilon \sigma \eta p \varepsilon ́ v a เ ~ \tau o ن ̀ ~ ~ o ́ \delta o ́ v \tau \alpha ร, ~ i . e ., ~ t o ~ p a r t ~ t h e ~ l i p s ~ a n d ~ s h o w ~ t h e ~ c l o s e d ~ t e e t h, ~ a s ~}$ people may do when laughing bitterly or sneeringly) by referring to the habit of horses, which bare the teeth when they are about to bite. Erasmus, though often enough on horseback himself, does not rely here on personal experience. Rather, he has in mind the Dutch proverb 'Hy lacht als een peert dat bijten wil' ('He laughs like a horse that wants to bite'). We also learn from his comment that 'een paardelach' (in Dutch; in German: 'Pferdelachen' or 'Rossgelächter', 'a horselaugh') was a current expression."

them for their copious use of adages (Ep. 126, ll. 127-43). He quotes at least eight proverbs from Poliziano in the Collectanea (nrs. 12, 38, 321, 396, 404, 477, 481, 496), but suppressed his name in the corresponding items in the Adagia, after he had identified relevant classical sources. On his use of works by Italian humanists in compiling the Collectanea see also Heinimann, 'Zu den Anfängen der humanistischen Paroemiologie'. A humanist source used by Erasmus for the Aldine 1508 edition of the Adagia is Aldus Manutius' own prefaces to various editions - a link which still needs to be explored.

$9 A S D$ II, 1, pp. 320-22, ll. 429-69. 'Idem,' says Erasmus, 'nunc vulgus nostratium effert subsordida quidem, sed tamen apta metaphora, cum aiunt: 'Prospectantum vetulo latrante cane.' (ibid. p. 322, ll. 466-67).

10 An interesting exception is the non-classical proverb 'E cantu dignoscitur auis' (Adagia 3121, ASD II, 7, p. 108, ll. 194-99), which Erasmus probably took from an Italian humanist source: 'Refertur et hoc a quibusdam,' he says, 'etiam si mihi nondum apud idoneos autores [i.e. ancient authors] repertum.' See Singer, s.v. Vogel, nrs. 1-10, for medieval versions (Latin and German) of the proverb.

11 Adagia no. 2401 'Risus Sardonius', $A S D$ II, 5, p. 290, ll. 44-45: 'Quem morem [to uncover the teeth] aiunt equis etiam inesse, si quando parent mordere, unde vulgo nunc risum 
Although the amount of vernacular proverbs cited in the Adagia is considerable, their role is subservient and instrumental. Erasmus uses them only as a means to clarify or illustrate a given ancient adage, or to demonstrate that it lives on in his own time. ${ }^{12}$ In his other works, vernacular proverbs, though far fewer in number, play a more important part. He uses them as additional evidence or even treats them on a par with ancient wisdom. Originating from and used by the linguistic community of his own day, they can serve as evidence and have a persuasive power in their own right; and so he employs them, like ancient adages, to confirm an assertion or to bolster an argument. He also uses them to lend wit and spice to his style. His use of vernacular expressions is not limited to a specific genre or period: they are found in a large variety of his works, ranging from the deeply serious De contemptu mundi to the more light-hearted Praise of Folly and Lingua, from various colloquies to a number of letters.

In De contemptu mundi, as its modern editor has seen, the sentence 'Concoloribus plumis aves una volitant' is a translation of the proverb 'Vogelen van eender veer vligen gern tsamen' ('Birds of a feather flock together'). This non-classical maxim is introduced as 'a proverb commonly used by everyone' ('proverbium quod vulgo nemo non dictitat'). ${ }^{13}$ Erasmus has paraphrased another proverb from the vernacular ('vulgi sermo') in the following passage: 'Quin esto iuxta vulgi sermonem quantum eis malitiae tantum sit et fortunae...' ('Let that popular proverb be true: "Their luck is as good as they are wicked" [but the day of revenge will come!]'). ${ }^{14}$ The underlying Dutch version is 'Hoe argher schalck hoe beter gheluck' ('The worse a scoundrel is, the better his luck'). In Lingua, 'Vasa quae sunt inania plurimum sonare' is the proverb 'Ledighe vaten clincken seer,' or, in its modern version, 'Holle vaten klinken het meest' ('Empty vessels make the most sound'). ${ }^{15}$ An interesting example

huiusmodi risum equinum vocant.' The Dutch proverb is quoted by Sartorius, no. 2479 . See Harrebomée, 2, p. 164. Another expression which may be added to Suringar's nearly exhaustive compilation of Dutch proverbs in the Adagia is found in no. 3674 (ASD II, 8, p. 112, ll. 904-911), 'Calliae defluunt pennae,' where Erasmus remarks that those who have been stripped of their possessions are said to have been 'plucked and sheared' ('Deplumati dicuntur ac detonsi qui facultatibus exuti sunt'). In ancient Latin, neither word is found in the metaphorical sense required here ('plundered, robbed'). Perhaps, he was thinking of the expression 'ghepluct en gheschooren' ('plucked and fleeced'); see $W N T$, s.v. scheren, 14, col. 473 .

12 See Suringar's compilation from the Adagia.

$13 A S D$ V, 1 p. $58,1.516$.

14 Ibidem, p. 70, $11.85^{2-53}$.

$15 A S D$ IV, 1A, p. 54, ll. 905-06. Other vernacular proverbs are found on p. 43, l. 574; p. 73, ll. 534-37; and p. 83, ll. 893-94. 
is in Exomologesis, Erasmus' treatise on confession (1524). ${ }^{16}$ Inveighing against craftsmen of his own time and their habit of cheating customers, he declares that this practice is so common and accepted that it has given rise to a proverb: 'adeo ut proverbio quoque dicatur unumquemque in suo opificio furem esse' ('so much so that there is even a proverb "Everyone is a thief in his own trade"'). This non-classical proverb is taken from the Dutch or German vernacular. The Dutch version is 'Elck is een dief tsijnder neeringe'; ${ }^{17}$ a German collection has 'Alleman ein deif [sic] in syner neringe. 18

De pueris instituendis has a vernacular saying on old parrots ('vulgi proverbio: Psittacum vetulum negligere ferulam.', 'an old parrot ignores the rod'). ${ }^{19}$ Erasmus cites it in the Adagia (no. 161) to illustrate the expression 'senis mutare linguam' ('to teach an old man a new language'). ${ }^{20}$ The (non-classical) saying is not attested in Dutch proverb collections, but Wander quotes 'Ein alter Papagai achtet die Ruthe nicht' ('An old parrot does not heed the rod'). ${ }^{21}$ Unfortunately, he gives no source. The question of Erasmus' familiarity with German is discussed below (p. 40).

$16 \quad L B \mathrm{~V}$, col. $164 \mathrm{C}$.

17 Quoted from Sartorius, no. 2697; it also appears in a Dutch proverb collection of the late fifteenth century; see Harrebomée, 1, p. 130 and 3, p. 160; WNT, s.v. dief, 3, col. 2519. Erasmus censures the same practice of cheating in his Explanatio Symboli, ASD v, 1, p. 317, ll. 33840: 'Nec ideo molitores, pistores ac vestiarii fures non sunt, rem alienam vel subtrahentes vel vitiantes, quia fit a plerisque.' I am grateful to Michael Heath for calling my attention to the proverb under discussion; his translation (and commentary) of Exomologesis will appear in Collected Works of Erasmus.

18 Quoted from the Monosticha (1514; 1, 73) by Antonius Tunnicius, a native of Münster in Westphalia. He provided each proverb with a translation in Latin hexameters. His translation of the proverb under discussion is 'Cleptes in proprio quaestu deprehenditur omnis.' See Wander, 1, s.v. Dieb, no. 155; compare ibid. 2, s.v. Handwerk, nrs. 23 and 68. See also Walther, no. $32247 \mathrm{e}$, which is based on Wander.

$19 A S D$ I, 2, p. 28, ll. 3-4.

20 Adagia no. 161, ASD II, 1, p. 274, ll. 461-62. In the prefatory letter to the Colloquies in the 1519 edition, Erasmus remarks that the epitome of Valla's Elegantiae, which he had made on the request of some acquaintance, was wasted on this 'old parrot': 'usque adeo plumbeum erat ingenium vetuli psitaci.' This phrase, too, is based on the proverb 'Senex psittacus negligit ferulam.' See $A S D$ I, 3, p. 73, 1l. 11-12; Ep. 909, l. 14; and, for the identity of the 'parrot' (Robert Fisher?), the introduction to the epitome or Paraphrasis, ASD I, 4, p. 193. Interestingly, Aldus Manutius quotes in Greek a precise parallel in the prefatory

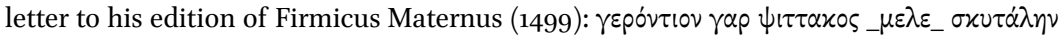
(Dionisotti and Orlandi, Aldo Manuzio editore, vol. 1, p. 28).

21 Wander, 3, s.v. Papagai. 
He occasionally employs a vernacular proverb in such a casual and implicit way that we need to depend on evidence from other works to recognize it as such. For example, in the Annotations on the New Testament, when paraphrasing Paul's words on the arcane wisdom of God, which should remain hidden from the profane crowd (1. Corinthians 2, 7), Erasmus uses the expression 'to cast roses before swine,' 'ne rosas obiiciamus porcis', where we would expect 'to cast pearls [margaritas] before swine,' as Matthew $(7,6)$ famously has it. $^{22}$ A casual variation, perhaps? No: in discussing the latter passage in the Collectanea (no. 4), Erasmus again quotes the expression 'Don't strew roses before swine,' which he explicitly identifies there as a vernacular saying of his own time: 'Manet hodieque vulgo tritum adagium "Ne suibus rosas obsperseris." '23 The Dutch expression is 'rozen voor de varkens strooien' or, as Sartorius has it, 'Ghy stroijt roesen voer verkens' ('You are strewing roses before swine'). ${ }^{24}$ Incidentally, the Bible passage in the Collectanea (no. 4) does not appear in the Adagia, in accordance with Erasmus' intention to limit the enlarged collection exclusively to ancient adages.

A rather problematic example is Erasmus' annotation on Paul's words addressed to the Corinthians, 'For you are the very seal of my apostleship' (1. Corinthians 9, 2). To elucidate the 'seal' metaphor ('sigillum'), he proposes the following parallel: 'Likewise, when we want to make clear that something is absolutely certain and unquestionable, we say (using commonly known expressions) that it is "attested by a sealed letter" ("quemadmodum vulgatis etiam proverbiis quod vehementer certum et indubitatum intelligi volumus, id dicimus "obsignatis literis testatum" '). The words introducing the expression seem to suggest that it is taken from the vernacular. Perhaps the Dutch saying referred to is 'Gij hebt daer segel ende brief af' ('You have seal and letter on that matter', that is, you can be absolutely sure that what I said is true) ${ }^{25}$

How can we recognize a vernacular proverb as such in Erasmus's works? In the examples given above, the words that introduce each proverb suggest that Erasmus was thinking of a vernacular expression. The next step to be taken is

\footnotetext{
$22 \quad A S D$ VI, 8, p. 6o, l. 333.

$23 A S D$ II, 9, p. 48, ll. 290-91.

24 Sartorius, Adagiorum chiliades tres, no. 419, quoted with other early sources by Suringar, no. 198; WNT, s.v. roos, 13, col. 1311. Cf. Walther, no. 31947 'Turpe rosas suibus, sanctum dare turpe catellis.' See also Singer, s.v. Schwein, nrs. 41 and 44.

25 Quoted by Sartorius, Adagiorum chiliades tres, no. 1550. See also Harrebomée, 1, p. 89 and $W N T$, s.v. zegel, 27 , col. 1568, which quotes another example of the metaphorical use of 'zegel en brief geven.' See also Singer, s.v. Siegel, no. 6, quoted from Luther (1542). I wish to thank Miekske van Poll-van de Lisdonk, the editor of Erasmus' Annotations, ASD VI, 8, for this information.
} 
to identify the proverb he had in mind. At this point, German and, above all, Dutch sources come in for consideration. A familiarity with Erasmus' native language is in fact indispensable.

Erasmus rarely refers to his native language by name, with the exception of De recta pronuntiatione, in which he occasionally compares features of pronunciation in a few regional dialects within the Low Countries. ${ }^{26}$ In the Adagia he contents himself with such vague formulas as hodieque vulgo dicitur,' 'apud nos,' 'apud nostrates.'27 Discussing the pronunciation of diphthongs in Greek, in his annotations on the New Testament, he specifically refers to lingua nostra, Hollandicam dico. ${ }^{28}$ Hollanders speak 'Hollands', a form of Dutch, 'Hollandice': in early Christianity, even common sailors spoke Greek or Latin, 'like we speak "Hollands"' ('nautae Graece Latineque loquebantur, quemadmodum nos Hollandice'), he writes from Basel to a Hollander. ${ }^{29}$

In addition to the vernacular, Erasmus occasionally draws on popular beliefs in the Low Countries concerning health and the human body. In De pueris instituendis he recalls that when struck in the face by some object, an expectant mother immediately plucks it away and transfers it to a less obvious, hidden part of the body. By doing so, the inevitable deformation of her child is transferred from its face to a different part of its body. From the context it is clear that Erasmus himself shared this widely held belief, which has it that a pregnant woman must not be frightened because the evil impression is transmitted to the foetus. ${ }^{30}$ Even though Erasmus' attention is focused predominantly on the ancient world and that of early Christianity, memories and associations connected with the Low Countries crop up in many of his works. ${ }^{31}$

In the following I focus on the Colloquies and attempt to present an exhaustive discussion of proverbs which are probably taken from the vernacular.

26 See Chomarat, Grammaire et rhétorique chez Érasme, 1, pp. 111-18; Poelhekke, 'The Nameless Homeland of Erasmus'.

27 See Suringar, iv.

28 'Apud Gallos adhuc audias diphthongum oi et $a i, o u$ et $e u$, in fide [foi], facto [fait], fulgure [foudre] seu pulvere [poudre] et duo [deux], itidem in lingua nostra, Hollandicam dico, in foeno [hooi], tenaci [taai], sene [oud], mendacio [leugen].' LB VI, col. $399 \mathrm{~F}$.

29 Ep. 1469, ll. 139-40.

$30 \quad A S D$ I, 2, p. 27, ll. 12-16. The passage has been clarified by IJsewijn, 'A Passage of Erasmus, De pueris instituendis, Explained', who points out that the belief under discussion is still alive in Flanders. See also Roodenburg, 'The Maternal Imagination', and my 'Dutch Proverbs and Ancient Sources', p. 362 and n. 40.

31 I here paraphrase an observation made by IJsewijn, who has been so kind as to read an early version of this chapter. 
A clear example is found in the dispute between the learned lady and the abbot, Colloquium abbatis et eruditae ('The abbot and the Learned Woman'). Opposed to learning in women, the abbot comes up with the following objection: 'I have often heard the common saying "A wise woman is twice foolish"' ('Frequenter audivi vulgo dici foeminam sapientem bis stultam esse'), to which the lady retorts, 'That saying is common indeed, but it is used only by fools' ('Istuc quidem dici solet, sed a stultis.'). ${ }^{32}$ The saying is the Dutch proverb 'Een wijze vrouw is tweewerf zot.'33

In Convivium profanum ('The Profane Feast', 1522) one reads: 'It is hard to accustom an old dog to a leash' ('Difficile est canem vetulum loris assuescere... Vetulus canis non facile assuescit loro.'). ${ }^{34}$ This is the Dutch proverb 'Oude honden sijn quaet bandich te maken. ${ }^{35}$ Erasmus identifies it as a vernacular proverb in the Adagia, no. 161, where he uses it to illustrate the expression 'senis mutare linguam' (to teach an old man a new language), saying: 'A popular but nonetheless elegant proverb has it that it is too late to accustom old dogs to leashes' ('vulgo quidem, attamen haudquaquam ineleganter dicitur, serum esse canes vetulos loris assuefacere'). ${ }^{36}$ In the same colloquy he also quotes a metrical variant of this proverb, which he probably took from a medieval Latin source; it appears in Walther's dictionary of medieval proverbs, no. 2936, 'Colla canum veterum nequeunt attingere lora.'

In the opening scene of Convivium religiosum ('The Godly Feast', 1522), Erasmus contrasts life in the countryside with the bustle of the city. He then censures the greed of priests and monks, 'who for the sake of gain usually prefer to live in populous cities, following the precept of a certain blind beggar who took pleasure in the jostling of a crowd because, he would say, business is where the people are' ('caeci cuiusquam mendici cui dulce erat premi turbis hominum, quod diceret illic esse quaestum, ubi esset populus'). ${ }^{37}$ The same anecdote appears in Adagia no. 2945 'Qui eget, in turba versetur' ('Those in

$32 \quad A S D$ I, 3, p. 407, ll. 133-35.

33 See below, pp. 40-41.

$34 \quad A S D$ I, 3, p. 201, ll. 2464-65; p. 49, 1. 553.

35 Quoted from Proverbia communia (a fifteenth-century collection of Dutch proverbs) by Harrebomée, 1, p. 30; 3, p. 115. Suringar, no. 206. An anonymous translation of the Colloquies, first published in 1622 , reads, " $T$ is swaer oude honden bandts te maecken. [...] Een ouden hondt laet zich niet licht aen den bandt wennen' (337 IK). The early Dutch translations of the Colloquies are discussed by Bijl, Erasmus in het Nederlands tot 1617, pp. 273-99. For bibliographical descriptions see Van der Haeghen, Bibliotheca Belgica, 2, E 756-63. I have used the translation of 1622 (E $\left.75^{8}\right)$.

$36 \quad A S D$ II, 1, p. 275 , ll. $470-71$.

$37 \quad A S D$ I, 3, p. 231, ll. 13-14 = p. 221, ll. 13-14. 
need should hang around in a crowd'). Here Erasmus points out that he took the anecdote from the vernacular ('hodiernis temporibus vulgo iactatur fabula de caeco mendico') and suggests that the saying uttered by the beggar is also of popular provenance ('sententiam populari ioco celebrem, ibi quaestum esse, ubi sit hominum frequentia'). The Dutch saying referred to is 'Bi dat volc leyt de neringe' ('Business is where the people are'). ${ }^{38}$ Erasmus associates it with a blind beggar. Later sources put it in the mouth of a fishmonger. Petrus Rabus of Rotterdam, who translated (and annotated) the Colloquies in the late seventeenth century, recalls 'the Dutch proverb about the fishmonger who wheeled his cart into church, saying, "Business is where the people are." 39

In A Dialogue Between a Liar and a Friend of Truth, Philetymus remarks that liars are also prone to stealing; 'this vice,' he tells the liar, 'is closely related to yours, as is also attested by a popular proverb' ('Hoc vitium esse tuo cognatum testatur etiam populare proverbium.'). ${ }^{40}$ Modern commentators hold that the reference is to the medieval Latin proverb 'Mendax est furax' ('A liar is also a thief'), which appears in Walther's dictionary. ${ }^{41}$ Erasmus, however, quotes a very similar proverb of Dutch provenance in Lingua, his treatise on the uses and abuses of language, which was published just two years after the colloquy (1525). There he writes: 'Nec temere vulgo dictum est Ostende mihi mendacem, ego tibi ostendam furem.42 The proverb Erasmus had in mind is 'Wijst my een loegener [leugenaar], Ick wijse v en dief' ('Show me a liar, I'll show you a thief') ${ }^{43}$ Incidentally, the name Philetymus means 'friend of truth' $\left(\varphi \iota \lambda-\varepsilon^{\prime \prime} \tau \nu \mu \circ v\right)$, not 'friend of honour' ( $\left.\tau \mu \eta \dot{)}\right)$. In fact, a scholium in the early editions explains the name Philetymus as 'amans veritatis,' while interpreting Pseudocheus (the liar's name) as 'fusor mendaciorum,' that is, one who 'pours forth lies'; the second part of this compound is apparently derived from $\chi \frac{\varepsilon}{\varepsilon} \omega .{ }^{44}$ The name was probably inspired by the title of Lucian's dialogue Philopseudes, 'The Lover of Lies.'

38 See Suringar, no. 188, who quotes from Servilius, Adagiorum epitome (1545), p. 219.

39 'Of gelijk 't Hollandsche spreekwoord is van den man, die met sijn mosselwagen in de kerk reed, zeggende: by 't volk is de nering'. See also Harrebomée, 1, p. 393.

$40 \quad A S D$ I, 3, p. 320, ll. 10-12.

41 No. 14643 a; see also Singer, s.v. lügen, nrs. 192-95.

$42 \quad A S D$ IV, 1A, p. 83, ll. 893-94.

43 Gemeene Duytsche Spreckwoorden. Kampen, 1550, p. 57; Kloeke, Kamper spreekwoorden, p. 32. Harrebomée, 1, p. 131. It is significant that Arnoldus Montanus quotes the same Dutch proverb in the margin of his edition of Erasmus's Colloquia (Amsterdam, 1658), 244. See the scholia in the 1531 edition, p. 966. Erasmus also uses the word 'pseudocheus' in Ep. 1531, l. 43 . 
In Convivium poeticum ('The Poetic Feast', 1523), the hilarious host calls his maidservant Margareta names, to which she replies in her down-to-earth way: 'I don't care, calling me names won't make me any fatter or thinner' ('Istae nomenculaturae nec obesiorem me reddunt nec macilentiorem.'). ${ }^{45} \mathrm{Her}$ (non-classical) expression may well be of vernacular provenance; perhaps it represents the Dutch phrase 'niet vet en niet mager' ('neither fat nor thin'). ${ }^{46}$ Commentators agree that Margareta is based on Margarete Büsslin, Erasmus' Xanthippe, who kept house for him during his residence in Basel and Freiburg (even to think here of his other Margaret, the learned daughter of Thomas More, would be inept and 'bot' to use an Erasmian expression). ${ }^{47}$ It is tempting therefore to surmise that a phrase of German origin underlies her reply. No such phrase, however, is found in Wander's Sprichwörter-Lexikon.

Nomenclatura is a learned term from Pliny's Natural History, Erasmus' favourite encyclopaedia. That the housemaid should use it achieves a comic effect, if only because she employs it in connection with terms of abuse. That she should mangle it as 'nomenculatura' is burlesque, because it suggests culus and, perhaps, culina (kitchen), the place where she is supposed to stay. Anyway, it is a nice example of Küchenlatein or 'culinaria elegantia,' as Erasmus once put it. ${ }^{48}$ Perhaps he was also thinking of the form nomenculator, a common variant of nomenclator in classical sources; ${ }^{49}$ it denoted a slave who told his master the names of those he met in the street.

When her master tells her to return to the kitchen, Margareta defiantly replies with 'the old saw "It's easier to call up a devil than to drive him away"'

$45 \quad A S D$ I, 3, p. 345, l. 30.

46 Harrebomée, 2, p. 50 (no sources given). The early translation of 1622 (329 D) reads: 'Sulcke toenamen, en maken my noch vetter noch magerder.'

47 'Hominem stupidum [...] vulgo dicimus "bot" pro "Boeoto", he notes in an adage, entitled 'A Boeotian pig' (no. 906, ASD II, 2, p. 419, l. 140). He refers to the same word in The Shipwreck; see below. On his housekeeper see Contemporaries of Erasmus, s.v. Büsslin; and Bierlaire, La familia d'Érasme, pp. 90-91. Another servant present at the feast described in the colloquy is given the name Mus (p. 349, l. 169; p. 351, l. 230; p. 356, l. 394), which has a double meaning: 'mouse' and 'parasite'; see Adagia 2468, entitled 'Muris in morem.' (ASD II, 5, p. 331, ll. 70-77.

$48 A S D$ I, 3, p. 78, l. 6o. Perhaps, Erasmus owed the phrase to Valla and his apologias against Poggio Bracciolini (1452-1453). Valla qualifies one of Poggio's barbarisms as a 'culinarium vocabulum' in Apologus, a witty kitchen-dialogue between a scholar and his cook about the Latinity of Poggio's letters. See the edition by Camporeale, 486, and Pfeiffer, Ausgewählte Schriften, pp. 183-87.- 'Nomenclatura' is the normal form in Erasmus ('mention of the name'): Epp. 531, l. 551; 549, 1. 13; 658, 1. 14; 2379, 1. 278.

For instance, Martial, Epigrams, 10.30.23; Macrobius, Saturnalia 2.4.15. 
('Vetus dictum est: Proclivius est evocare cacodaemonem quam abigere.').50 Perhaps this, too, is taken from the vernacular; it is not attested in Walther, nor is it in Dutch proverb collections; ${ }^{51}$ but Singer quotes from Sebastian Franck the proverb 'Es ist gut den teuffel zu hauss laden, aber böss sein abkommen' ('It's easy to invite the devil into one's house, but hard to get rid of him'). ${ }^{52}$

Margareta's reply leads to a comic attempt to get her out of the way. Having at last withdrawn to her kitchen, she sourly remarks that the dinner-party has lasted long enough; that the guests have been at the table too long: '(ait) satis diu sessum esse. 53 The unusual phrase, with 'sessum' used in the passive voice (and not as a supine), is probably meant to be another comic example of poor Latin: it is hard to find any parallel for this phrase in classical literature. It is tempting to assume that Erasmus is playing on the German form gesessen (from the verb sitzen).

It should be pointed out that evidence of Erasmus' familiarity with German is rather scant and contradictory. ${ }^{54}$ Writing around 1498 to a German from Lübeck ('cuidam Lubecensi' - probably the father of his pupil Christian Northoff), Erasmus apologized for not using the German vernacular, declaring that his German was inadequate: 'I have written to you to the above effect at greater length than I should; and have also done so in Latin, not because I despise your native tongue and mine but because it would not have been easy for me to write in the vernacular, nor would it have been easy for you to understand what I wrote' ('Haec pluribus ad te scripsi quam debui, et quidem Latine, non fastidio linguae nostratis, sed quod neque facile id potuissem, neque tu facile intellexisses.') ${ }^{55}$

It seems reasonable to assume that Erasmus picked up at least some German from 1521 onwards, during his many years' residence in Basel and Freiburg im Breisgau. When he pretended in 1522 not to know the language, Duke George of Saxony, who wanted him to read certain works of Luther (and to write against the reformer), refused to take this claim seriously. ${ }^{56}$ Moreover, when Leo Jud, a supporter of Zwingli, published a biased account of Erasmus'

\footnotetext{
$50 \quad A S D$ I, 3, p. 345 , l. 38 .

$5^{1}$ The early translation (1622, p. $329 \mathrm{EF}$ ) reads: ' $\mathrm{t}$ Is een out [een] spreeck-woort, men can den duyvel veel lichter doen comen, als wech heeten gaen.'

$5^{2} \quad$ Singer, s.v. Teufel, no. 198; see also Wander, 4, p. 1061.

$53 \quad A S D$ I, 3, p. 356, l. 399.

54 See the excellent discussion by Chomarat, Grammaire et rhétorique chez Érasme 1, pp. 137-44, who concludes that his knowledge of German was sufficient for daily use. Halkin, 'Érasme et les langues', pp. 573-74, arrived at the same conclusion.

55 Ep. 82, ll. 39-41. Translation R.A.B. Mynors and D.F.S. Thomson, $c W E$, 1, p. 167.

$5^{6} \quad$ Ep. 1313, ll. 84-85; and Ep. 1340.
} 
view of the Eucharist, Erasmus composed a detailed refutation within two months after its appearance (May 1526), even though Jud's tract was written in German (Des Hochgelerten Erasmi von Roterdam, und Doctor Luthers maynung vom Nachtmal unsers Herren Jesu Christi). And still he claimed not to know the language. ${ }^{57}$

As a matter of fact, he knew it well enough to review translations of his own works. ${ }^{58}$ On the other hand, he ordered an assistant to translate a German ecclesiastical document (Erklärung zur Kirchenordnung) for his own use, which proves that as late as 1533 his knowledge of German was inadequate. ${ }^{59}$ There are just a few scattered references to German words in his letters. In 1523 he reports about a big fish, a trout, caught in the Lake of Konstanz, which the natives call 'throtta' ('piscem ingentem, quam throttam appellat vulgus.'). ${ }^{60}$ In Freiburg (1534), he is suffering from a disease, which to his mind is similar to gout, the illness he knew so well; the epidemic is called 'Souch' and 'Gesucht' by the locals, he notes, which is best rendered as 'the disease' (compare Sucht and Gesüchte) ${ }^{61} \mathrm{He}$ also refers to a German term in the 1533 edition of the Adagia, no. 3906, where he explains the expression 'More silent than an Areopagite' (a member of the highest judicial court of Athens) by referring to the Westphalian vemen of his own day, or local courts of law, whose members were bound by solemn vows of secrecy; they are commonly referred to as 'Certi', he says: 'Certi vulgo dicuntur'; he was apparently familiar with the vernacular terms for these judges: Gewissene and Wissende, meaning 'those who know.' ${ }^{62}$ All in all, one can assume that he became increasingly familiar with Alemannic-German during his stay in Basel and Freiburg.

Obviously, such formulas as 'vulgo dicitur' do not always signal a vernacular expression. ${ }^{63}$ In many cases, Erasmus simply refers to ancient usage, the common practice in classical Latin, as is clear from the very end of his introduction to the Adagia (chap. xiv). Besides this, he may also be referring to

\footnotetext{
57 Erasmus's refutation, entitled Detectio praestigiarum, appears in ASD IX, 1, pp. 233-62; 'Meam sententiam,' he says, 'quoniam Germanice nescio Latine dedi' (p. 245, l. 285).

58 See Holeczek, Erasmus deutsch, 228-29.

59 See Allen's note on Ep. 2804.

6o Ep. 1342, ll. 396-97.

$61 \quad E p .2906$, ll. 125-26: 'morbum, quem vulgo Souch appellant. Eo dicuntur multi hic laborare.' See also Epp. 2916, l. 6 and 2918, 1. 40.

62 See the comments in the German proverb collections of Johannes Agricola (1529) and Eberhard Tappe, a native of Westphalia (1545), quoted by Grimm, s.v. Gewissen (III), 4: 6218; s.v. wissend, 14: 772; and by Suringar, no. 19.

63 See Tournoy and Tunberg, 'On the Margins of Latinity?', pp. 161-65.
} 
(a) the common practice among users of Latin in general,

(b) common use as such, without specific reference to any language,

(c) the general use in both Latin and the vernaculars (mostly his native language).

Examples from the Colloquies and other works illustrate each of these three categories. (a) 'A common proverb has it (credible enough, but bad Latin), "Novus rex, novus lex", "New king, new law"' ('Vulgo iactatur proverbium, non tam vanum quam parum Latinum, "Nouus rex, novus lex" '). ${ }^{64}$ The correct version ('nova lex') is quoted by Walther, no. $18860 \mathrm{c}$ (a non-classical proverb). It is clear that Erasmus does not mean here the vernacular, although the same proverb occurs in French ('De nouveau roy nouvelle loy', 'A new king comes up with a new law'). ${ }^{65}$ Another example of (a) is 'the common saying "So many men, so many opinions"' ('vulgo dici solet, Quot homines, tot sententiae'), ${ }^{66}$ although Erasmus notes in the Adagia (no. 207) that the same aphorism is also current in the vernacular ('Nihil vel hodie vulgo tritius est quam haec Terentiana sententia'). ${ }^{67}$ Yet another example is found in Lingua, where Erasmus remarks that people who become jolly when they drink wine 'are generally called tipsy, not drunk' ('vulgo qui vino facti sunt hilariores bene poti dicuntur, ebrii non dicuntur, nisi lingua deliret'). ${ }^{68}$ Here 'vulgo' (generally, in common use) is intended to contrast with a specific class of people, namely philosophers, mentioned in 1.599 .

An example of (b) occurs in Puerpera ('The New Mother'): 'It is commonly said that one should overlook a first try' ('Vulgo dicitur veniam deberi primum experienti.'). ${ }^{69}$ There is no reference here to the Greek origin of the expres-

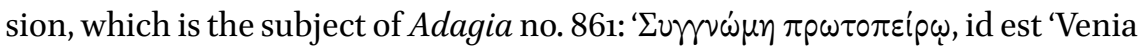

$64 A S D$ I, 3, p. 438, ll. 10-11. Luther quotes the same formula (with 'novus lex') in his Auslegung des 101. Psalms (1534-35; WA 51, p. 209, ll. 22-23), which he may well have borrowed from Erasmus' colloquy (1524), just as he used a few Erasmian adages in the same work (see the notes there on pp. 211 and 215). Even so he forbade his children to read the Colloquies.

65 Quoted by Le Roux de Lincy, Le livre des proverbes français, p. 547, from a sixteenthcentury proverb collection, namely an appendix to Mots dorés de Caton. See also Singer, s.v. neu, nrs. 74 and 75: 'Nouveau prince, nouvelle loy'

$66 \quad A S D$ I, 3, p. 589, ll. 120-21.

$67 \quad A S D$ II, 1, p. 319, l. 395 .

$68 A S D$ IV, 1A, p. 44, ll. 603-04; it should be noted that the phrase 'bene potus' (well warmed, tipsy) is either taken from Cicero, Ad familiares 7.22, or from Nonius Marcellus, 231 (quoting Lucilius, fragment 1044, ed. Werner Frenkel).

$69 \quad A S D$ I, 3, p. 469, l. 569 . 
primum experienti.' " 70 Another example of (b) is found in the same colloquy, where Eutrapelus seeks to persuade the young mother to breastfeed her baby herself rather than hiring a wet nurse: 'Or do you suppose,' he asks rhetorically, 'that the common saying "He drank in his wickedness with his nurse's milk" has no basis?' ('An putas temere vulgo dici "Iste maliciam cum lacte nutricis imbibit"?'). ${ }^{71}$ The expression is adapted from a statement by Cicero in Tusculanae disputationes. ${ }^{72}$ This detail is of interest for any analysis of Erasmus's method of writing, but it is irrelevant to the meaning of 'vulgo' in the given context. The same is true of an expression in a dialogue between a young man in love and a girl (Proci et puellae). Reluctant to marry, Maria raises the following objection: 'Marriage is commonly called a halter' ('Vulgus coniugium capistrum vocat').$^{73}$ Erasmus took the expression from Juvenal's satires (6.43): 'He [a notorious womanizer] puts his silly head into the halter of marriage' ('stulta maritali iam porrigit ora capistro') ${ }^{74}$ Here, too, this detail has no relevance to the context.

As regards (c) the following (non-classical) proverb is perhaps a case in point. It is found in medieval Latin and, in a slightly different form, in various vernaculars as well. In Pietas puerilis (1522) Erasmus puts a 'common saying' into the mouth of Erasmius: 'Angelic boys turn into Satan ${ }^{75}$ when they grow old' ('Aiunt vulgo pueros angelicos in satanam verti, ubi consenuerint'). ${ }^{76}$ Walther quotes two similar proverbs from medieval Latin sources: 'Angelicus iuvenis senibus satanizat in annis' and 'Saepe senex Sathane datus est puer angelicus ante. 77 A Dutch version is 'Jonge engeltjes zijn gemeenlijk oude duiveltjes' ('Young angels usually become old devils'). ${ }^{78}$ German and French

\footnotetext{
$70 \quad A S D$ II, 2, p. 382, l. 205.

$71 \quad A S D$ I, 3, p. 467, l. 529 .

72 Cicero', Tusculanae disputationes 3.1.2, quoted in Adagia no. 654 'Cum lacte nutricis'; $A S D$ II, 2, p. 180, ll. 138-42.

$73 \quad A S D$ I, 3, p. 286, l. 318.

74 That the source is Juvenal is apparent from De contemptu mundi, ASD v, 1, p. 5o, ll. 27475 'vt caueas ferreo isti capistro ora porrigere' and The Praise of Folly, ASD IV, 3, p. 80, ll. 162-62 'Qui vir, obsecro, matrimonii capistro velit praebere os [...]?'

75 For the sense of 'vertor' compare 'Ex Hollando versus es in Gallum,' ASD I, 3, p. 137, l. 405. Thompson translates 'angelic boys become limbs of Satan.' (CWE 39, p. 91).

$76 \quad A S D$ I, 3, p. 172, l. 1520.

77 Walther, nrs. 1042 and 27273.

78 Quoted from sources of the second half of the sixteenth century by Harrebomée, 1, p. 166; 3, pp. 172-73. The 1622 translation of the Colloquies reads: 'Men segt gemeenlic, dat de gene die in haer kintsheyt Engelen zijn, out geworden zijnde, tot duyvelen worden' (388 A).
} 
sources have 'Die jungen engel werden alt teuffel' and 'De jeune angelot, vieux diable. ${ }^{79}$ In sum, the possibility that Erasmus is referring to vernacular variants cannot be ruled out. The same is true of an expression in the preface to Annotationes in Marcum. Checking and comparing readings and translations, he says with a sigh, involves a lot of running around among many manuscript volumes of the Bible; it is like 'looking for a needle in a heap [of hay]' ('At nos dum inter tot Graecos, Latinos, Hebraeos codices sursum ac deorsum discurrimus, velut aciculam, quod aiunt, in acervo quaerentes...')..$^{80}$ This expression is not found in this form in ancient texts. ${ }^{81} \mathrm{~A}$ Latin version of later (medieval?) origin is 'acum in meta foeni quaerere,' but the phrase is also quite common in various vernaculars. ${ }^{82} \mathrm{~A}$ Dutch version is 'een naald in een voeder hooi vinden' or, as Sartorius puts it, 'Ghy had wel eene naeld in eenen voeyer hoijs gheuonden' ('You would even have found a needle in a pack of hay'). ${ }^{83}$

To return to the Colloquies: a Dutch expression underlies a passage in Funus ('The Funeral', 1526). Here a Dominican mendicant friar and a parish priest are engaged in a violent quarrel over the last will of a dying man. 'I', brags the Dominican, 'am a Fully-Qualified Bachelor of Sacred Theology ('Sacrae Theologiae Baccalaureus Formatus'), while you are an idiot.' 'I,' the priest retorts, 'could make much better bachelors than you out of beanstalks' ('Ego baccalaureos multo te meliores nectam e stipulis fabarum'), ${ }^{84}$ which amounts to saying 'You are absolutely worthless.' It should be noted, first, that 'nectam' ('make by plaiting') wittily takes up 'formatus' in 'Baccalaureus Formatus' (a regular academic title, distinct from that of Cursor and other lower degrees); the priest is taking 'Formatus' in the literal sense, 'fashioned, shaped.' Secondly,

79 Quoted by Wander, s.vv. Engel (7) and Engelchen, 1, pp. 820-22; see also Singer, s.v. jung, nrs. 191-92, 197-207, 211-21. The Italian variant ('Angelo nella giovanezza, diavolo nella vecchiezza') can be disregarded, since Erasmus did not understand the language, despite his stay in Italy (1506-09); see Halkin, 'Érasme et les langues', pp. 575-76; 'Érasme en Italie', p. 39 and his n. 34. He once declared that he knew as little Italian as East Indian, 'vulgaris linguae vestratis tam sum ignarus quam Indicae'; see the anecdote in Apophthegmata 8, $L B$ IV, col. 363 E. He had some French but very little English; see Halkin, 'Érasme en Italie', pp. 575-78; Chomarat, Grammaire et rhétorique chez Érasme, 1: 144-47.

8o $\quad A S D$ VI, 5, p. 352, ll. $35-37$. Erasmus discusses the phrase 'sursum ac deorsum discurrere' in Adagia 285 .

81 For a close parallel (Plautus, Menaechmi 238) see Adagia 2620, entitled 'Vel acum inuenisses,' ASD II, 6.

82 See Arthaber, Dizionario, no. 258, who unfortunately fails to give sources.

83 Sartorius, no. 2698. See $W N T$, s.v. voeder, 22, col. 92; s.v. voer, 22, col. 243; and Harrebomée, 1, p. 331; 3, p. 233.

$84 \quad A S D$ I, 3, p. 540, ll. 103-05, 109-10. 
he alludes to a popular etymology of 'baccalaureus' as coming from 'laurel berry'. ${ }^{85}$ Third, his gibe depends on the notion that the stalks and stubble of beans are worthless stuff. A scholium refers to a Dutch proverb or expression. ${ }^{86}$ The anonymous commentator contrasts beanstalks, which are good for nothing, with straws of wheat, which are used for making hats and rain-coats: 'Ex culmis tritici nectuntur galeri, nonnunquam et pallia adversus pluviam. Faba caules habet grandes, intortos et fragiles, ad nihil minus utiles quam ad texendum. Est vulgo iactatum proverbium apud Batavos.' ${ }^{\prime 8}$ In fact, the Dutch word for dry beanstalks, bonenstro, is applied to useless things or stupid people, as in the phrase 'soo grof als bonen stroo' ('as rough and crass as dry beanstalks').88

Erasmus, with his hatred of braggarts and hypocrites, also ridicules the title Baccalaureus Formatus (and that of Cursor) in an anecdote in which he wittily describes a monk as 'theologiae bacalaureus, currens an sedens, formatus an mox formandus, incertum.'89

Another non-classical proverb is found in A Synod of Grammarians (Synodus grammaticorum, 1529): '[Many] eyes see more than one' ('Plus vident oculi quam oculus').${ }^{90}$ Erasmus quotes the same saying in a letter, written around 1489 in the monastery of Steyn and addressed to his Dutch friend Cornelius Aurelius of Gouda. In this early letter, the proverb is introduced by the formula 'quod vulgo dicitur.'91 Erasmus presumably had a Dutch proverb in mind:

85 See Farge, Orthodoxy and Reform in Early Reformation France, pp. 16-28; Weijers, Terminologie des universités au XIII ${ }^{e}$ siecle, pp. 173-80; Blaise, s.v. baccalarius, 5; Lexikon des Mittelalters, 1: s.v. baccalarius. The term is of feudal origin. It designated a young nobleman, ranking below knighthood; in many cases, as Weijers points out, he would serve as a squire. The title was usually derived from 'bacca lauri' (laurel berry). Erasmus uses this and other fanciful etymologies in a humorous dialogue in De recta pronuntiatione, ASD I, 4, p. 26, ll. 390-416.

86 I have used the 1531 edition of the Colloquia (Basel, Froben); the scholium concerned appears on pp. 992-93. Scholia were added to the Froben editions authorized by Erasmus from $15^{26}$ onwards; see CWE 39: xxvi-xxvii, and Bierlaire, Érasme et ses Colloques, p. 93. One would like to know the identity of the commentator. All that can be said is that he was a supporter of Erasmus who worked in close contact with the Froben firm. Perhaps, he received information from Erasmus himself.

87 Adagia, ed. 1531, pp. 992-93.

88 Quoted by Sartorius, no. 2599 as an equivalent to 'Pistillo retusior est' (Erasmus, Adagia no. 2521). Harrebomée, 1, p. 79; WNT, 3, s.v. boonenstroo. The translation of the Colloquies (1622, 266 B) reads 'Ick, seyde hy, soude veel beter Baccalaurien dan ghy zijt, uyt boonenstroo konnen draeyen.'

89 Adagia no. 1498, ASD II, 3, p. 478, 1l. 676-77.

$90 \quad A S D$ I, 3, p. 586, ll. 20-21.

91 Ep. 20, ll. 121-22. 
‘Twee ogen zien meer dan één' ('Two eyes see more than one'). ${ }^{92}$ Some doubt might arise from the fact that the Latin version appears in Walther's dictionary of medieval proverbs; ${ }^{93}$ but Walther's entry is misleading, in that it is not based on a medieval source, but on one dated $1616 .{ }^{94}$ Since there is no indication that the Latin version predates the time of Erasmus, I assume that he took the proverb not from a medieval Latin source, but from the vernacular.

In The Shipwreck (Naufragium, 1523), the narrator relates the silly behaviour of a superstitious fellow, which prompts his listener to exclaim, 'Blockhead! A Batavian, I presume?' ('O crassum ingenium! Suspicor fuisse Batauum'). ${ }^{95}$ The implied characterization of Batavians or Hollanders as blockheads apparently needed an explanation for the use of readers outside the Low Countries, for a scholium has been added, which states that Hollanders are commonly nicknamed 'crassi' ('vulgari ioco,' ed. 1531, p. 968). The reference is to their ethnic epithet bot, which covers the entire range of 'blunt, dumb, dull-witted, stupid, gullible. ${ }^{96}$ Stultitia alludes to it in her praise of folly, saying: 'Those Hollanders of mine - and why shouldn't I call them mine, since they worship me so zealously that they have earned thereby a widely used epithet' ('Hollandi mei-cur enim non meos appellem usqueadeo studiosos mei cultores, ut inde vulgo cognomen emeruerint?'). ${ }^{97}$ In this context, 'vulgo' ('widely used') means

92 Harrebomée, 2, p. 144; one may note, however, that the earliest sources given date from the seventeenth century. De Brune $(1636 ; 295,475$ and 480) has (in iambic verse) 'Twee oghen die zien meer als een' and 'Vier oogen zien veel meer als twee' (Four eyes see much more than two).

93 Walther, no. 19710 a.

94 Walther (19710 a) has taken the Latin version from Wander (s.v. Auge, no. 200), who refers to the German dictionary of Georg Henisch (1616), p. 149. Henisch quotes 'Vil augen sehen mehr als eins,' adding 'Plus vident oculi quam oculus,' without giving any source. It is possible that this Latin version goes back to Erasmus. See, however, Singer, s.v. sehen, no. 159 'Nonne plura quatuor oculi vident quam duo?' (Ps. Cyrillus 1, 10 page 16, 30) and 164 'Vier augen sehen mehr dann 2' (Franck I, 109v).

$95 \quad A S D$ I, 3, p. 328, l. 104.

96 Petrus Rabus translates in fact 'O bot verstand! Ik duchte dat hy een Hollander geweest is' (135).

$97 A S D$ IV, 3, p. 84, ll. 254-55. On the nickname see Wesseling, 'Dutch Proverbs and Ancient Sources in Erasmus' Praise of Folly', pp. 352-56; and 'Are the Dutch Uncivilized?', pp. 71-75. Rudolph Agricola from Groningen (1454-94) cites the 'proverb' 'Crassis crassa conveniunt' (Stupid ideas befit the stupid) in De inventione dialectica (see the close of his prologue; I owe the reference to Marc van der Poel). Is this somehow related to the nickname of Hollanders? Erasmus uses the same word-play in a colloquy: 'Vos crassi crassis delectamini.' $A S D$ I, 3, p. 347, ll. 84-85. 
specifically 'in the vernacular,' just as in Erasmus' remark 'Hominem stupidum ... vulgo dicimus "bot" pro "Boeoto".98

Returning to Erasmus' idiom, we need to point out a perplexing anomaly: his frequent use of 'solet' instead of 'solebat,' which runs counter to the ancient and the humanist usage. Surprisingly, none of his critics ever seized this opportunity to censure his Latinity. There is one clear instance in the Colloquies: 'Olim in conviviis myrtus tradi solet' ('It once was customary at dinner-parties to pass on a myrtle-branch'). ${ }^{99}$ But the feature is frequent in the Adagia; to give but one example: 'Qui molesti prolixique laboris finem adesse significabat dicere solet 'Terram video.' 100 Trapman (like Allen before him) has noticed four instances in a letter to Jodocus Jonas (1521). ${ }^{101}$ Pointing out that the phenomenon is not uncommon in Neo-Latin texts by other Netherlandish authors (16th century), he tentatively explains it as a Dutchism. ${ }^{102}$ As a matter of fact, the Woordenboek refers to the occurrence of the form pleeg as the imperfect tense (third person sing.) next to plag and placht (he/she used to, was accustomed to). ${ }^{103}$

\section{Epilogue: Erasmus' Estimate of His Native Language}

From Erasmus' use of Dutch proverbs and expressions one can infer that he was fond of his native language. At any rate, he treasured its store of proverbs, which he shared with the uneducated. The simple fact that it was his mother tongue, combined with his relative ignorance (resulting from disdain) of other vernaculars, may account for his predilection. There is no reason to accept Chomarat's assumption that his feelings of contempt towards the Dutch also encompassed his native language. ${ }^{104}$ It is true that his attitude towards his fellow countrymen was highly ambivalent and predominantly negative. $\mathrm{He}$

\footnotetext{
98 Adagia no. 906, end; $A S D$ II, 2, p. 419, l. 140.

$99 A S D$ I, 3, p. 562, l. 45; see also p. 547 , l. 337 and p. 623, l. 81.

100 No. 3718. See also $A S D$ II, 2, p. 280, ll. 974-75; II, 8, p. 67, ll. 43-45 ('soleant' for 'solerent'); p. 98, ll. 564-65; p. 206, ll. 645-46 ('Olim rei solent esse moesti ... quo iudices ad misericordiam inflecterent'); p. 228, ll. 16-18; p. 253, 1l. 579-8o.

101 Ep. 1211, ll. 89, 138, 456, 513.

102 Trapman, 'Solet Instead of Solebat in Erasmus and Other Neo-Latin Authors'. The same usage (four times) is in Goswinus van Halen's Vita of Rudolph Agricola (ca. 1525), as Fokke Akkerman kindly informed me.

$103 W N T$, s.v. plegen, 12, 1, col. 2483; and de Vriendt, pp. 117-19.

104 See Chomarat's otherwise admirable chapter on Erasmus and his native tongue; Grammaire et rhétorique chez Érasme, 1, pp. 107-25, esp. p. 108.
} 
did hold them in contempt for their indifference to higher culture and the humanist movement, their lack of appreciation of his own achievements, their fondness for 'compotationes' and 'comessationes,' their banal concerns and idle table-talk; ${ }^{105}$ but this did not lead him to despise their language as such. His mother tongue probably had a special emotional value for him. As the language of his childhood, Dutch fragments, phrases and sayings kept coming to his mind throughout his life, even after he had turned his back on the uncivilized Hollanders (1501) and, subsequently, on the hostile theologians in Brabant (1521). This enhances the reliability of Beatus Rhenanus' account of Erasmus' death, which has it that his last words were 'lieuer Gott', in Dutch: 'lieve God' —or Alemannic — Iiebe Gott'—or German—'lieber Gott'.106

While on the whole it is true that Erasmus disdained vernacular languages in general, it should be recalled that he was in favor of vernacular translations of the Bible. Furthermore, he stressed the relative worth and importance of the vernaculars in his last major work, the manual for the use of preachers (Ecclesiastes, 1535). It is in the context of precepts on preaching in the vernacular that he admits that each national tongue has, at least potentially, its own particular charm and suggestive power. He accordingly recommends, although at the very end of the list, the reading of vernacular works by eminent literary authors. Though ignorant of Italian himself, he refers by way of example to Dante and Petrarch. Even classical scholars, he declares, should not regard any language as barbarous as long as it serves to draw people to the Gospel. ${ }^{107}$

His passion for the 'bonae litterae' and concomitant disdain for vernacular languages explains why he rarely refers to national literatures. He once made a scathing remark on the medieval chivalric romances of Arthur and Lancelot, which to his regret were very popular in his own time. Old wives' tales about tyrants, he calls them. God forbid that a young prince- the future Charles v—should read such rubbish!108 He had no use for chivalric ideals and

105 See Wesseling, 'Are the Dutch Uncivilized?'.

106 See Van der Blom, 'Die letzten Worte des Erasmus' and above, n. 19.

107 'Quamuis eruditis iucundior sit Latinorum aut Graecorum lectio, tamen charitati christanae non videbitur sermo barbarus per quem proximus ad Christum allicitur,' $A S D \mathrm{v}, 4$, p. 264, 1l. 402-05; see also Chomarat's introduction, Grammaire et rhétorique chez Érasme, pp. $5^{-7}$.

108 'At hodie permultos videmus Arcturis, Lanslotis et aliis id genus fabulis delectari, non solum tyrannicis, verum etiam prorsus ineruditis, stultis et anilibus.' Institutio principis Christiani, ASD IV, 1, p. 179, ll. 427-180, esp. l. 430. 'Nugacissimis fabulis pleni libri Gallice scripti,' as a colloquy has it ( $A S D$ I, 3, p. 405, l. 87). Charles' chief educator, Guillaume de Croy, was a promoter of the traditional chivalric ethos; see Tracy, Politics of Erasmus, 59-6o. 
courtly love: a teacher of 'civilitas,' he promoted politeness based on modesty and consideration. Surprisingly, a remark in the 1528 edition of the Adagia suggests that he did appreciate a certain type of popular theatre: commenting on the Greek term sciamachy, or fighting with shadows, he refers to farces of his own day which feature a bragging soldier waging combat against an imaginary opponent, who is merely his own shadow: 'Ludus umbraticae pugnae durat etiam hodie non illepidus,' he notes. ${ }^{109}$ Entertainment of this kind involved a lot of boasting and verbal violence. In his last major work he makes a crushing remark on the rhetoricians or rhétoriqueurs, the members of the chambers of rhetoric, calling them 'rhetoristae'; they take pleasure in excessive rhyming and producing foolish jingles. Those preaching in the vernacular should not imitate them. ${ }^{110}$ But the very scarcity of references of this kind indicates that he took little interest in vernacular literature. Significantly, he never mentions Machiavelli, a political thinker with whom he shared many interests, and whose Prince he could have read in Agostino Nifo's Latin translation.111

109 Adagia no. 3548, ASD II, 8, p. 50, l. 627.

110 'qui se rhetoristas appellant.' Ecclesiastes 3, $A S D$ v, 5 p. 136, l. 627; p. 152, l. 968; see also Chomarat, Grammaire et rhétorique chez Érasme, 1, pp. 130-31.

111 De regnandi peritia, Naples 1523. 